\title{
Democracy and Human Rights in Nigeria: Appraising the 2015 General Elections in Ebonyi State
}

\author{
Nwobi Obiora Isaac* \\ Department of History and International Relations Ebonyi State University, Abakaliki \\ *Corresponding Author \\ Nwobi Obiora Isaac
}

\section{Article History}

Received: 05.08.2020

Accepted: 13.08 .2020

Published: 23.08.2020

\begin{abstract}
Democracy which is conceived as a system that gives periodic opportunities for the masses to choose their leaders has a lot to do with the rights of citizens in the society. It guarantees individual's right of existence and promotes total participation of people in governance, while ensuring equality to all people. The debates about the role of human rights in the promotion of democracy and democratic practices, is in consonance with the degree to which there should be massive participation in the election/electoral practices in Nigeria. Therefore the extent to which human rights play positive or negative roles in Nigerian democratization process depends on the existing institutions in discouraging electoral irregularities such as violence, thuggery and in encouraging or facilitating mass participation which aims at ensuring transparency, free, fair and credible elections. This paper adopts relative depravation as a theoretical framework to argue that Nigeria's democratic practices have no respect to human rights but a promotion of electoral violence, thuggery, snatching of ballot boxes and killing of people. The materials for his paper were sourced from secondary data. The paper concluded that weak institutions entrenched in Nigeria's democracy promotes electoral violence, the spate of which led to human rights abuse in Ebonyi State. Hence the paper recommended that the institutions that allow for the practice of democracy should be judicially reviewed to discourage politicians from perpetuating electoral violence.
\end{abstract}

Keywords: Democracy, Human Rights, Nigeria, Appraising, General Elections.

\section{INTRODUCTION}

There is no trace of sarcasm in holding the view that elections in Nigeria have never recorded the total hallmark of democracy that manifest in absolute transparency, fairness and equal participation to all people. This is because as elections come, the values of democracy in Nigeria keep waning conspicuously and become completely absent in extreme cases.

Nigeria as an independent state has vacillated between civilian democratic rules to military regimes starting from October 1, 1960 to 29 May, 1999 when Abudulsalam Abubakar, handed over to President Olusegun Obasanjo as a democratic elected president. Nigeria became a Republican State in 1963 following the 1966 military coup that toppled the first republic.

The second republic came from 1979 to 1983, when the fourth military coup ousted and took over the government. By 1993, there was presidential election that could have returned Nigeria to $3^{\text {rd }}$ republic and civilian democratic rule. This election was annulled by President Ibrahim Babangida who threw Nigeria into the dudgeon of political instability. By this, Babangida regime was preceded by Ernest Shonakan who was later preceded by Sani Abacha. The trauma of Abacha's military rule lent him a credible dictator, the spate of which was the execution of Ken Saro Wiwa and other Ogoni activists that was labeled an abuse to human rights by international community.

With the demise of Abacha, Abudulsalami Abubakar took over and promised to return Nigeria into democratic State. This promise was fulfilled following the elections that brought Obasanjo as the democratic elected president on May 29, 1999. Ordinarily, as an emerging democracy, Nigeria should have shown remarkable improvement in the

Copyright @ 2020: This is an open-access article distributed under the terms of the Creative Commons Attribution license which permits unrestricted use, distribution, and reproduction in any medium for non commercial use (NonCommercial, or CC-BY-NC) provided the original author and source are credited. 
process of electing its State officials but since then, elections in Nigeria have manifested in human rights abuse, disenfranchisement, and wanton destruction of property, maiming and killing of people. The incidence of this manifested in the volatile selfish display of the power of incumbency and blood thirsty politicians who wanted to rig themselves in power by every means.

The 2015 general elections in Ebonyi State have provided us with litmus test to which weak democratic institutions have resulted in human rights abuse. It was observed with total dismay that the 2015 general elections in Ebonyi State were conducted using the instruments of AK 47, thugs, military men and machetes. This is against the campaign of UN General Assembly which proclaims the Universal Declaration of Human Rights as a common standard of achievement for all peoples and nations [1].

The 2015 general elections have come and gone in Nigeria but how democratic were the elections to the protection of human rights? The problem that is confounding millions of Nigeria is that, rather than the 2015 elections being the Panacea to the restoration of democratic confidence in the people, the elections have succeeded in placing Nigerians in a deeper confused state of democracy. The scenario seemed boring and disappointing in the entire electoral process which owned its enormity of fraud on April as witnessed in Ebonyi State general elections. The international observers precisely the EUEOM, AU and local election monitors might have scored the elections relatively above average in terms of transparency and fairness but did the elections reflect the serenity of electoral processes that brought Obama, Hollande and Ellen, J. Sirleaf just to mention but a few into power?

The trouble with such democratic pretext or what has come to be referred to in some quarters of the nation as shadow democracy is indeed embracing. By this, Agbor maintains that it has eroded the people's confidence in the leadership and the entire Nigerian system thereby reducing the level of national identity [2].

The 2015 general elections made a caricature of the country in the comity of nations and presented the citizens as a bundle of unserious persons in relation to other citizens of more stable and responsible country. The implication is that while other countries are at the peak of democratic practices, achieving stability and dividends that are permitted by their strong democratic institutions, Nigeria is still tilting at windmills of rigging, corruption and inchoate democratic processes. The vicissitudes of rigging and other related election problems have gone a long way to show that our chances of competing favourably with other citizens of other stable countries will continue to be marred by the negative stigma already created in the minds of politicians. The whole of unending rigging sprees which characterize Nigeria's elections are as a result of the country's reliance on faulty Electoral Acts, rule of law and constitution. The upward drift from manual accreditation to card reader and use of soldiers during the elections has not been enacted in the electoral Acts or in the constitution and thus becoming inadmissible during the post-election court proceedings. This resulted to disenfranchisement of the electorates and the violation of human rights during elections.

Therefore, from all indications, the old system of manual accreditation has failed to ensure free, fair and credible elections in Nigeria and it is degrading fast the Nigeria's electoral integrity. In 2015 general elections, Nigeria had just begun to experiment electronic voting process, during voter's registration and the election itself. This system should have been better if it had been given test run to perfect the whole processes. Therefore, the issue of card reader failed in number of ways: (1) it deprived the electorates the opportunity to cast their votes, (2) it became a system that was fractioned on disjointed model and permitted by the "will of the mights".

By this, it is obvious that a country that has a faulty electoral process like Nigeria would find development very farfetched. The operational method of the entire electoral process needs to be corrected to avoid easy manipulation and to ensure equal opportunity and guarantee right of participation to all people. It is on this ground that democracy in Nigeria can give freedom to all people.

\section{Conceptual Clarification: Democracy}

Democracy is derived from the political discourse of ancient Greek City States especially that of Athens, in the fourth and fifth centuries B.C, where it denoted a particular kind of regime or political formation [3]. It means literally "rule by "or power of the people" and more accurately, perhaps, "common people [4]".

The meaning of democracy is heavily contested simply because it means different things to different people and thus becomes amorphous and imprecise in terms of definitions. As an etymological term, democracy is an ancient Greek word, which means "demokratia" which is the combination of "demos"- the people, with "kratos"- the "rule" "power" or strength". In this manner, the literal denotation of democracy is "rule by the people that culminates in a popular form of government. Therefore, democracy is simply people's rule, and participation in decision making through developed operational constitutional institutions. 
Democracy conceptualized in this manner strives to ensure that there is total participation in the process of decision, provision of equal opportunities and freedom to all people, protection of human rights and respect to human dignities. It is on this ground that democracy seems to be given the best and one of the succinct definitions during the Gettysburg Address by the U.S President-Abraham Lincoln on November 19, 1963 as the "government of the people by the people and for the people [5]. Democracy can be seen as "a government in which everyone has a share". This implies a government in which majority have comparative advantages in the affairs of the government. To Seeley it is a form of government in which, "the governing body is a comparatively large fraction of the entire nation". Therefore, democracy does not imply a vast majority to participate in the affairs of the government [6]. Indeed, the ranks of the critics of democracy are being fortified by those who believe in the doctrine of the elite. According to them, democracy is founded all together on wrong premises. It assumes that the common man understands political issues in all their complexity and that he has the capacity to govern himself. Both of these assumptions are challenged by the advocates of the doctrine of the elite. According to them, a vast majority of people are incapable and incompetent to govern themselves. Therefore, government should be vested in the hands of the few who are wise and capable [7].

Democracy is being attacked today from various angles, both by reactionaries and revolutionaries. It is attacked with much vehemence by believers in autocracy and dictatorships. Many of these advocate the gospel of direct action according to which a well-organized, strong willed and assertive minority should impose its will upon the helpless majority by remorseless terrorism, if necessary. This explains African kinds of democracy in the contemporary quest for administrative stability, democratic state, party cohesion or ideology, protection of human rights and respect for rule of law.

Democracy has remained largely confusing because of its associated terms like peoples democracy, fuller democracy, guided democracy, liberal democracy just to mention but a few. Liberal democracy remains the World's dominant model, historically and contemporarily used by very many countries in the international system [8]. Of all these, liberal democracy also known as bourgeois democracy or elite democracy is identified with the following indexes: popular election and representation, universal suffrage, protection of fundamental human rights, freedom of speech, rule of law and constitutionalism, popular sovereignty, popular representation, functional representation, consensus and accommodation, peaceful resolution of disputes, capitalism and free market, political rights, autonomy vs control, persuasion vs coercions and reciprocal vs unilateral controls [9].

Democracy can be defined in the following three categories: (1) Formal (procedural), defines democracy according to rules and meaning of polities (minimalist), (2) Substantive or "Real" defines democracy in terms of outcome of politics (minimalist), (3) Middle- range defines democracy as a balance of rules and outcome.

\section{THEORETICAL FRAMEWORK}

The theoretical analysis for this study is anchored on "Relative Deprivation" to explain the link between the cause of violence and the feeling for deprivation among people in any social gathering. By this, it allows an objective comparison between the situations of the individual or group with the rest of the society.

However, relative deprivation emphasizes the individual experience of discontent when being deprived of something to which one believes oneself to be entitled for. It is a term generally used to describe feelings or measures of economic, political or social deprivation that are relative rather than absolute. The term is inextricably linked to the similar terms of poverty and social exclusion [9]. The concept of relative deprivation has important consequences for both behaviour and attitudes, including feelings of stress, political attitudes and participation in collective actions. This explains why political analysts have cited relative deprivation as a potential cause of social movement and deviance, leading to extreme situations to political violence such as rioting, terrorism, civil war and other instances of social deviance such as crime [10].

This theory was coined by American sociologist W.G Runciman in 1966 to explain the violence that occurs where individuals or groups subjectively perceived themselves as unfairly disadvantaged over others perceived as having similar attributes and deserving similar rewards. The relevance of this theory explains the spate of violence in Ebonyi State during the 2015 general elections to which some electorates were disenfranchised from voting, with wanton destruction of property, killing, arrest and detention.

\section{Human Rights}

The issue of human rights has largely remained the concern of modern states in the global society. The desire for an ideal society where all the rights and privileges, respect for human dignities and where freedom of speech and association thrill has led to UN Universal Declaration of Human Rights in 1948 with a focus on the belief that all of us were created equal in the image and likeness of the creator. ${ }^{11}$ This implies that men are created equal and have the 
perpendicularity for equal rights, justice, peace and security of their lives. The needs for a secured life have led to the categorization of man's struggle into stages.

First is the conception stage which is the period man battles with bacteria for survival in his mother's womb. The second is the infancy stage which is the stage he is challenged by natural phenomena such as hunger, sicknesses, understanding and ability to talk, while the third stage is the adult stage which is the stage he is embattled with cases of disasters as war and conflict, insecurity, discrimination, violation of rights and exclusion from the act of governance. These ideas characterized the history of man with continuous struggle such as the struggle for survival, struggle for economic and political emancipation, struggle for equality and social justice, struggle against racial/gender bigotry and against every form of inhumanity of man to man [12]. In other words, all these struggles are strategically made towards safeguarding human rights from tyranny, abuses and violations. By this, the International Community has made spirited efforts to enforce the protection of fundamental human rights on every nation state. These efforts drew strength from the 1948 Universal Human Rights Declaration which its preamble reads in part as:

Whereas recognition of all inherent dignity and of the equal and inalienable rights of all members of the human family is the foundation of freedom, justice and peace in the World. Whereas disregard and contempt for human rights have resulted in barbarous acts which outraged the conscience of mankind, and the advent of a world in which human beings shall enjoy freedom of speech and belief and freedom from fear and want has been proclaimed of the highest aspiration of the common people. Whereas it is essential, if man is not to be compelled to have recourse, as a last resort, to rebellion against tyranny and oppression, that human rights should be protected by the rule of law... Now the UN General Assembly proclaims the Universal Declaration of Human Rights as a common standard of achievement for all peoples and nations [13].

Therefore, it is incumbent on a state like Nigeria to ensure that the rights of her citizenry are fully and adequately protected. Thus Oruche argues that:

For a right to be called human, it must be possessed by all human beings. Again, because it is same right that human beings possess, it must be possessed equally by all human beings, we can rule out as possible candidates any of those rights which one might have in virtue of occupying any particular status of relationship. They are rights that can be claimed equally against any and human beings [14].

In other words, the term "right" here has been vigorously used to refer to those natural endowments that are entrusted to man by virtue of his birth. Aro Gilbert holds that it consists of a moral power to claim something as one's own and it points to the general goodwill and conscience [15]. Right is also a natural due a moral claim and legal entitlement accrued to man by virtue of being a member of any political society. Therefore rights are sacred and sacrosanct and various institutions and government are duty bound to protect and safeguard human rights for the progress of the society.

\section{Elections, Electoral Processes, Fraud and Violence in Nigeria}

Election represents the main process through which people exercise their constituent power and sovereignty. By this, people decide at periodic intervals in order to determine who gets what, how and why [16]. In other words, election constitutes the gamut of strategic element of the democratic process, the implication of which goes to show that election is the heart of democracy. Therefore in democracy, periodic elections become crucial in order to consolidate institutions that lead to democratic government in a state.

The importance of elections in the process of democracy goes to show that election is the mechanism by which people are elected into office. For Obikeze and Obi, elections are the means through which people of a country, organization or union chooses and exercises some degree of control over their representatives [17]. What is important here is that election is conceived as an activity that remains the most crucial aspect of political participation. Indeed, a succinct definition about election is that given by Nnoli when he refers to election as the process of choice agreed upon by a group of people which enables them to select one or few people out of many to occupy one or a number of authority position [18]. It is a process of choice if backed by rules and regulations that are defined to ensure certain degrees of fairness and justice to everybody. In other words, election is the most modern and acceptable form of recruitment into offices and a crucial element for democratic process.

However, the election of political officers into various offices is defined by the processes permitted by law of the country otherwise known as electoral process. Therefore, electoral process is the overall method or procedure of electoral activities which are systematically designed to be followed for the proper conduct of an election [19]. It is the objective, systematic, comprehensive and procedural planned of activities that will lead to the conversion of votes in the determination of winner and loser in an election. 
Electoral process defines the processes in which political leaders are being elected into offices. For a country to have a strong electoral process, it must have the backing of constitution and the electoral laws which will not make it prone to frauds. Fraud is defined in terms of irregularities recorded during or before the elections such as snatching of ballot boxes, distribution of fake result sheets, rigging and double voting. Therefore, suffice it to say that the process that leads to election in Nigeria is characterized with fraud, the magnitude of which is electoral violence where party victory is highly depended on the number of billboards and posters one tore and persons killed during the elections. For this reason, violence according to Anifowose becomes an illegitimate use of force to achieve a purpose [20]. Therefore, it is an act considered illegal, unlawful or illegitimate use of threat to further one's achievement or success. Violence has so many forms such as electoral violence, political violence and violence behaviour. Political violence is conceived as the use of force or threat of physical act carried out by an individual or individuals within a political system against another individual(s) with the intent to cause injury or death to person(s) and damage or destruction of property, and whose objectives, choice of targets or victims, surrounding circumstance, implementation and effects have political significance that tend to modify the behaviour of others in the existing arrangements of power structure and some consequences on the political system [21].

Therefore, electoral violence entails all forms of violence that emanate at any stage from the time of the election which could lead to differences in opinions and practices election campaign. Hence electoral violence occurs at three stages- Pre election violence stage which normally takes place during party primaries, stage violence that occurs during the election period and the post-election violence arising as a result of disaffection on the outcome of election results. By this, electoral process, fraud and violence are inextricably linked to constitute human rights abuse in a democratic state.

\section{Appraising the 2015 General Elections in Ebonyi State}

The 2015 general elections in Ebonyi State have remained largely the same with the elections of 2003, 2007 and 2011. These elections were characterized with widespread of violence, fraud and irregularities. The records and antecedents of these past elections have gone to show that Ebonyi State has a culture of electoral violence. These ranged from wanton destruction of property worth of millions, rioting, killing and shooting. The spate of this violence manifests in the uniqueness and features that characterize elections in Ebonyi State. Therefore, the 2015 general elections in the state were contested by multiparty structure which comprised the ruling People Democratic Party (PDP), Labour Party (LP), All Progressive Grand Party, (APGA) and All Progressive Congress (APC). The activities of these parties were sown on violence which translated the voting powers of the electorates into cut-throat politics. By this, Aro Gilbert asserts that the pre elections activities were characterized with campaign full of violence with remarkable deaths [22].

The onslaught of the 2015 general elections in Ebonyi State reflected on the fierce battle between the ruling People Democratic Party and the newly formed Labour Party. The results of the pull saw Engr. Dave Umahi pulling a total of 289, 867 to defeat his close rival of Labour Party, Sir Edward Nkwegu who pulled a total of 124, 817 votes [23].

As part of the post elections development, the Labour Party, APC and APGA jointly petitioned Prof Attahiru Jega and called for the cancellation of Ebonyi Governorship elections. In other words, the opposition parties cited the widespread irregularities, killings, and wanton destruction of property during the April 11, 2015 governorship and State House of Assembly elections in Ebonyi State as the reasons for the cancellation. The petition was signed by Comrade Obiya Sabastine Friday, Hon. Ben Nwabashi and Comrade Jerry Obasi- the State Chairmen of LP, APC and APGA respectively.

The three parties which took part in the election complained that the ruling People Democratic Party (PDP) connived with some INEC adhoc staff and security agents to fraudulently falsify results after chasing their poll agents away from election centers. In a related development, part of the petition reads.

We hereby forward this petition to request that you immediately conduct an in-depth investigation of large scale of fraud, manipulation, intimidation and falsification of results in the governorship and House of Assembly elections held on April 11, 2015. It is clear that the "results" were gotten through a criminal and fraudulent process [24].

With the widespread of irregularities and fraud that characterized Ebonyi State elections of 2015, the PDP has demonstrated their expertise in rigging the elections to their advantage. Emphatically, there were cases of fake distributions of EC\&A (I) and (II) of various polling stations as was witnessed in Ishielu Local Government, intimidation, snatching of ballot boxes through soldiers, shooting and double voting. The result of the poll saw PDP winning the governorship, the whole seats in both Senate and House Rep., and 22 State House of Assembly members. 


The table below shows the result of 2015 general elections
\begin{tabular}{|l|l|l|}
\hline Type of Election & Political Party & No. of Federal Constituency \\
\hline Presidential Election & PDP & \\
\hline Governorship Election & PDP & \\
\hline Senatorial Election & PDP & 3 \\
\hline House of Rep. & PDP & 6 \\
\hline House of Assembly & PDP & 20 \\
& LP & 1 \\
& PPA & 1 \\
\hline
\end{tabular}

Source: Internet online result, 2015.

\section{General Elections and Human Rights Abuse}

Beginning from 1999 when Nigeria began to transit to another Wave of democracy, electoral violence has shown that human rights abuse is among the factors that hinder the promotion of democracy and democratic practices in Nigeria. The spate of human rights abuse as witnessed during the elections of 2003, 2007, 2011 and 2015 in Ebonyi State have proven that Ebonyi State has a culture of electoral frauds, violence and irregularities.

On 11 April, 2015 there were reported cases of extra judicial killing as people set to elect their leaders in governorship and State House of Assembly election in Ebonyi State. According to S. Kalu, about seven persons including Mr. Mike Nworie, a former chairman of the people Democratic Party in Ishielu Local Government Area had been reportedly killed in governorship and state House of Assemble election in Ebonyi State on Saturday. In Ezza South Local government Area, Six young men were reportedly killed by thugs. While in Okposi town, Ohaozara Local Government Area, political thugs allegedly working for the ruling party and led by a perceived gangster, called "Chopper" attacked the Labour Party and All Progressive Congress agents at different polling units. The political thugs who were said to have ridden with a team of "soldiers" in a Hillux Van marked with bold "Army" inscription allegedly bundled five polling Unit agents at PU 007, Mgbom Okposi, PU 007, Achara Ward and the polling unit at Enecli Akuma Primary School, Okposi Okwu Ward [24].

In Ishiagu, Ivo Local Government Areas there was a standing order by a high ranked official of the federal government to police officers and officials of the state security service who were detained in a private facility to ward off the supporters of opposition parties. In Ohaukwu and Ikwo Councils, some hoodlums snatched money meant for polling agents while several persons were left with broken Limbs at Ndiagara and a woman dead at Ikwo Local Government Area. Still in Ikwo, at Omege Noyo polling unit, Mike Ojon was killed during the collation of the results. In Ohaozara Local Government Area, Mr Ifeanyi Onu was shot dead by political thugs that were pitched in the battle of supremacy between two Leading contending political parties; the people Democracy Party, and the Labour Party on March, 2015.

In February 2015, the Labour Party rally in Ejikwu Primary School, Owutu Edda Mr. Okporie Arisi was shot with seven persons badly injured and properties worth millions of naira were destroyed, which included three thousand plastic Chairs, two tents of forty five canopies and campaign material [25]. In the same vein, the Labour Party Vehicle in Ohaozara, and the campaign bill boards were vandalized by the PDP led thugs, while the campaign team of the senatorial candidate of Labour Party was massively attacked in Onueke Ezza South and Ikwo Local Government respectively [26]. In Afikpo South, Ikwo and Ohaukwu, the APGA campaign offices and buses were burnt down during the campaign.

Indeed, during the one day official visit to Ebonyi State by Assistant Inspector General of Police (AIG) in charge of zone 6, it was reported that Ebonyi State has the highest number of electoral offences in the zone [26]. The spate of this violence has gone to show that human rights are most affected as people don't vote freely during the elections and have no right to express or associate with parties of their choice which ostensibly leads to disenfranchisement.

\section{CONCLUSION}

Following the models lay down by the 1948 Universal Declaration of Human Rights and the 1950 European Convention of Human Rights and in compliance with the decision of the 1958 constitutional conference, the protection of the fundamental Human Rights in Nigeria has assumed a serious constitutional matter. By this, individual, groups or associations have the right to exercise their freedom as permitted by the constitution of the country.

To exercise these rights, they are empowered to elect their leaders and associate with any organization that is formed within the provision of the constitution. To this extent, it becomes the duty of the government at all levels to ensure the safety of the citizenry. This concept is highly found in democracy where individuals are entitled to their opinions. Therefore, democracy and human rights share high sense of interconnection as both ensure the protection and 
promotion of individual rights which are the indexes that qualify the capacity and capability of states. Therefore, these practices are not found in the practice of democracy in Ebonyi state where human rights are vehemently abused thereby denying the electorates the opportunity to cast your votes. This was largely the case that characterized the conduct of 2015 general election in the Ebonyi State as people were seen staying at home than going out to cast their votes.

\section{RECOMMENDATIONS}

1. That the institutions that allow for the practice of democracy should be judicially received to discourage politicians from perpetuating electoral violence.

2. Political parties should be more committed in sensitizing and educating their followers on the dangers of electoral violence.

3. The cost of running elections in Nigeria should be reduced to give equal opportunities to those who intend to run election.

\section{EFFERENCE}

1. Kukah, M. H. (2015). Transition to Democracy: Can Nigeria Ride the Wave. Text of a Convocation Lecture Delivered at the Ebonyi State University, Abakaliki on April 25th.

2. Ijim-Agbor, U. (2004). Democracy and Electoral Malaise in Nigeria: Towards an Effective Approach to Free and Fair Election. African Journal of Political and Administrative Studies, 1(1).

3. U.I. (2004). Agbor, 133.

4. Jay, R. (1994). Democracy in Ecceleshall, Georghengan, Jay, Kenny, Mackenzie and Wilford (Eds) Political Idiologies, and Introduction, Routledge, London, 118.

5. The democracy in http://en.m.Wikipedia org./Nki/ Gettysburg-Address. (2006). Retrived on February 20, 2006.

6. Asirvatham, E., \& Misra, K. K. (2008). Political Theory, New Delhi, S. Chand and.

7. Asirvatham, E., \& Misra, K.K. (2006), 447.

8. Chukwu, A.G., \& Chukwu, C. (2015). Democracy Human Rights and Electoral Violence: The Nigerian Experience in the Fourth Republic, in A. Itumo and J. O Nkwede, Democracy and Electoral studies: A Reader, Enugu, 9 DeEnovy Print Media, 78.

9. Aniara, A.S. Globalization and Youths Decadence in Ebonyi state. unpulished

10. Gurr, T.R. (1970). Why Men Rebel, Princeton University press.

11. Kukah, M.H.( 2015), 9.

12. Chukwudozie, C.M.N. (2000). Introduction to Human Rights and Social Justice Enugu, Ochusa Printing and Publishing Company Ltd, 1.

13. Kakah, M.H. (2015). 9

14. Oruche, J.O. Basic issues on Human Rights Protection Quoted in C.N. Chukwudozie introduction to Human Rights and Social Justice, Enugu, Ochuba Publishing Ltd. P.3.

15. Nwobashi, H.N. (2015). Election and Electoral process in A. Itumo and J.O Nkwede (ed) Democracy and Electoral Studies: A Reader, Enugu, De = Envoy print media, 115.

16. Obikeze., \& Obi, E. (2004). Elements, Structure and Organisation of Government, Onitsha Book Point Ltd, 23.

17. Nnoli, O. (2003). Introduction to politics, Enugu, SNAPP PRESS, 220

18. Nwobashi, H.N. (2015). 120.

19. Anifowose, R. (1982). Violence and politics in Nigeria: The Tiv and Yoruba experience. Nok Publishers International.

20. Chukwu, A.G. (2016). Media, Democracy and Election, Violence in Ebonyi State. In D.I. Ajaegbo and K.J. Ani (ed) Communication and Contemporary Historical Development in Nigeria Essays in honour of elder Ngwoke Ngwuoke, Abakaliki, De Joe Press, 225.

21. Ogbonnaya, O. (2015). PDP Cardidate, Dave Umahi wins Ebonyi Guber poll, In Leadership Newspaper, 12.

22. Ogbonnaya, E. S., Clarke, G., Shanahan, F., Dinan, T. G., Cryan, J. F., \& O’Leary, O. F. (2015). Adult hippocampal neurogenesis is regulated by the microbiome. Biological psychiatry, 78(4), e7-e9.

23. Kalu, S. (2015). Nigeria decides: From PDP Chairman, six others killed in Ebonyi State Election Violence in Sunday punch, 2015 accessed in http://www.the sheet.ng.

24. Kalu, S., Koirala, M., Khadka, U. R., \& Anup, K. C. (2015). Soil quality assessment for different land use in the Panchase area of western Nepal. International Journal of Environmental Protection, 5(1), 38-43.

25. Ituma, O. S., \& Chukwu, A. G. (2016). 2015 gubernatorial election and democratic consolidation in ebonyi state. South east journal of political science, 2(2).

26. Ogbonnaya, E. S., Clarke, G., Shanahan, F., Dinan, T. G., Cryan, J. F., \& O’Leary, O. F. (2015). Adult hippocampal neurogenesis is regulated by the microbiome. Biological psychiatry, 78(4), e7-e9. 